\title{
The Cinema of Manie van Rensburg (conclusion)
}

\author{
By Martin P. Botha
}

Spring 1998 Issue of KINEMA

\section{THE CINEMA OF MANIE VAN RENSBURG: POPULAR MEMORIES OF AFRIKANER- DOM (Conclusion)}

The name, Manie van Rensburg, is virtually unknown in Europe and the United States of America. Recently, some of his work was screened at a South African film festival in Amsterdam at the Kriterion cinema and I had the honour to present a lecture there on 7 October 1995 regarding Van Rensburg and his work. His work was also highlighted in a small retrospective during October 1996 at the Vrije Universiteit Brussel. The following is the conclusion of the article the first part of which was published in KINEMA Fall $199 \%$.

\section{9-1948: The Rise of Afrikaner Nationalism}

Fusion, and the consequent split between General Hertzog and D.F. Malan, was of the greatest significance in the history of Afrikaner nationalism. Although Malan's Purified National Party was numerically exceptionally weak, confined largely to the Cape Province and with only 19 seats in the House of Assembly, within 15 years it had established itself as a dominant force in Afrikaner political life and as the new governing party in South Africa. In its ideology and institutional grounding in Afrikaner life, the party represented a fundamental departure from the Hertzog traditions of Afrikaner nationalism.

The focus of Hertzog's nationalism was the legal status of Afrikaners. As such, his principal objectives had been the securing of language equality for Afrikaners, the civil rights of Afrikaans-speakers, and the constitutional independence of South Africa. His definition of an Afrikaner was not narrowly exclusive, and embraced not only Afrikaans-speakers but also English-speaking whites who were loyal to South Africa and accepted language equality. A powerful sense of 'South Africa First' distinguished his nationalism, and this helped to shape his foreign and economic policies.

Malan's new party was formulating a far more aggressive nationalist ideology. Strongly republican, and ethnically exclusive, it stressed the distinctiveness of Afrikaner culture, and saw as a priority not merely the legal parity of Afrikaners but their social and material predicament. These objectives were given institutional form in a range of political, cultural, and economic agencies with and through which the party worked to articulate Afrikaner aspirations, and to develop and entrench its hold on Afrikaner voters.

When the British Prime Minister, Neville Chamberlain, announced on Sunday 3 September 1939 that Britain was at war with Germany, Hertzog presented his colleagues with his decision that South Africa should adopt neutrality, a decision which he had reached in the knowledge that Malan's Purified National Party would support him. The Cabinet was irrevocably split by the decision. Smuts, however, proposed an amendment that the Union sever its relations with the Third Reich, and refuse to adopt a position of neutrality. Hertzog, however, compared Hitler's behaviour with his own struggles in the cause of Afrikaner freedom. Smuts replied that it was impossible to reconcile neutrality with South Africa's obligations towards Britain and the Commonwealth. Hertzog's motion was defeated. He resigned, and Smuts was invited to form a government. On 6 September the new government issued a proclamation to sever relations with Germany. More than two million South Africans volunteered for service in World War II, including 120 thousand blacks.

In The Fourth Reich this split between Smuts and Hertzog is portrayed in a long sequence. Relations between supporters of Smuts and those of Malan worsened, as depicted in Heroes. Under the leadership of Hans van Rensburg, the Ossewabrandwag, ${ }^{(1)}$ a right-wing organisation, had initially enjoyed cordial relations with Malan and Hertzog's newly formed National Party, and many prominent party members had joined the movement. The Ossewabrandwag grew massively during the early war years; by 1941, its membership had reached between 300 and 400 thousand. It also became increasingly militaristic in style. A crack elite corps, the Stormjaers ${ }^{(2)}$ was established. Acts of sabotage carried out by members of the movement embarrassed the National Party, which, as Malan primly pointed out, relied on constitutional methods to achieve its objectives. 
It is within this context that both Heroes and The Fourth Reich must be understood. During these stormy times of the Second World War the hatred between Smuts and Malan supporters was blatantly obvious.

\section{Heroes (1985)}

Heroes portrays an Orwellian world during the beginning of the forties in a linear narrative structure and a realistic style. Van Rensburg returned to the format of Verspeelde Lente. The viewer sees figures, faces and farmhouses in dark spaces, while paranoia and corruption reign everywhere. The complexity of this socio-political situation was remarkably well-portrayed for a local television production about this period.

The friendship between an Afrikaner, Hendrik (played by Ian Roberts, one of the regulars in Van Rensburg's work) and an Englishman, Patrick Joseph (played by Neil McCarthy), is the central focus of the narrative. Both are in love with an English-speaking nurse, Isadora Collins. Hendrik works in a garage for an elderly Jew, Mr Hymie Galgut. Isadora becomes a lodger with the Galgut family whose son, Ira, wants to join up in the war to fight Hitler and fascism. His father replies by identifying the enemy as being local feelings of anti-Semitism, telling his son: "We don't have a country. We have only ourselves." Mr Galgut tends to exploit his employees, a practice to which Ira strongly objects.

The tension between those South Africans who have joined the war effort and those who haven't, is visible from the first sequence in the movie when Hendrik accidentally bumps into soldiers at the station. The soldiers demand an apology. The initial feelings of anti-Semitism are also visible in a sequence in which Isadora buys food in a shop and some Afrikaners make rude remarks about Jews.

Patrick remarks: "We are not all alike. I am English."

Isadora replies: "One can be rude in any language."

The scene changes to the Stormjaers trying to sabotage the railway line. General Fourie of the Ossewabrandwag arrives on the scene and is seriously hurt after an explosion. Hendrik, on his way home in his car, is asked by a member of the Stormjaers, Uncle Willem (Mees Xteen, who played Vlok in Die Perdesmous), to help him tow his car to a farmhouse.

He tells Hendrik: "We Afrikaners must stand together, Hendrik." The wounded body of General Fourie is in the car, but being hidden from Hendrik. Unconsciously Hendrik, who is not politically polarised towards the right, becomes involved in Stormjaer activities.

Patrick is also not politically polarised, although his father, an English doctor, tries to persuade him to join the armed forces in the war. Patrick remarks that he will only join up if the Germans attack Jamestown. The change in the characters of these two men, initially friends, makes up the narrative of Heroes, a development in character that is no less remarkable than that of Pop in Verspeelde Lente.

Van Rensburg also portrays the tension in the relations between the Afrikaner nationalists in the town and the Jewish family. In order to get medicine for the seriously injured General Fourie, some Stormjaer members kill Patrick's father and flee with the medicine. Hendrik meets with members of the Stormjaers, including Gerhard Lombaard (played by Ryno Hattingh, who also plays the Robey Leibbrandt character in The Fourth Reich). They try to persuade him to join the ranks of the Stormjaers.

The episode has a brilliant sequence when the three friends, Patrick, Hendrik and Isadora, got to the local cinema to watch a movie entitled 'Singapore Woman'. On the screen a propaganda newsreel film with Wagnerian music flickers full of images of heroic young men joining the war. When 'God Save the Queen' plays on the soundtrack, some Stormjaer members refuse to stand and they are attacked by soldiers. Later, the Afrikaner Nationalists tell Isadora, Patrick and Ira:

We would like to show you English that we don't have grudges against individuals. We just don't accept the English king and the English flag and the English country ... It is time you people realised that you're not living in an extension of England. You people came here to try to take this country away from us and now you are standing with one leg here and the other in England.

When Patrick's father dies in hospital, the scene intercuts with the death of General Andries Fourie. The ideological polarisation now begins in the lives of Hendrik and Patrick. The latter is embittered and changes from a womaniser into a determined volunteer for the war. He objects to Hendrik's involvement with the 
Stormjaers at Stutterheim. Now, Heroes becomes a vivid exploration of growing fascism in South Africa with uncomfortable parallels with similar right-wing sentiments in contemporary South Africa.

Patrick tells Hendrik: "It is impossible to stay neutral in this war." When he tries to make love to Isadora, he suffers from impotence. In a moving scene the friends have a farewell party in the fields and nothing is the same after that.

Patrick joins the armed forces and his mother collapses, but finds emotional strength in Isadora, while Hendrik becomes a member of the Stormjaers after a quarrel with Mr Galgut, who becomes more and more isolated in the community. The growing polarisation mirrors the same tendencies in South Africa during the PW Botha regime. The extreme of this polarisation in the film is portrayed in a gruesome physical assault on the young Jew, Ira, forcing the Jewish family finally to leave the community.

Van Rensburg's major achievement in the film is in giving every side a human perspective: the Jewish family, the Afrikaner Nationalists, and the family of Patrick. People are caught up in the spiral of violence. One of the most remarkable scenes in the film is when Hendrik is sworn in as a member of the Stormjaers. Van Rensburg repeats this ritual several times in The Fourth Reich. He touches here at the heart of Afrikaner extremists, in an emotional ceremony that frightens the viewer due to its emotional intensity. Hendrik is now part of 'the war within South Africa' (as opposed to the war outside the country) and the ideology of Afrikaner nationalism. He begins to cut ties with Isadora and the communication between them suffers.

Hendrik is arrested after he tries to sabotage the railway line and realises later he has been set up by his new friends who are not prepared to perform the act themselves because of the danger involved. In his discussions with the police, explaining his motives, he refers to the traumas of urbanisation, the drought on the farms and the absence of capital to save Afrikaner farmers. In the concentration camp, Hendrik's humiliating physical check-up and his detention again show clear parallels with the 1980s State of Emergency and the thousands of detentions without trial.

Both Hendrik and Patrick betray their friends, returning home with physical and emotional scars. This makes the title of the film highly ironic. Neither the volunteers in the war nor the Stormjaers fighting their own war inside the country can be regarded as heroes in Van Rensburg's filmic world.

Hendrik, disillusioned by the Stormjaers, informs on them to the security personnel in the camp. (This incident is reminiscent of a similar act in The Fourth Reich when Jan Taillard betrays Robey Leibbrandt at the end of the movie.) Patrick too, acts in a cowardly fashion when he tries to run away from a hand grenade that falls between him and his buddies on the battlefield, instead of throwing himself on it, and giving up his life in order to save theirs. He is, however, wounded in the back. Hendrik becomes the Van Rensburg outcast, living in paranoia on the edge of society. At the end of the film he is shot by the fascist, Gerhard.

The Fourth Reich (1990)

The director's cut of The Fourth Reich, also linear in structure and realistic in style, is Van Rensburg's greatest achievement. The film is basically structured as a thriller, a hunt by a dedicated Afrikaner policeman, Jan Taillard (Marius Weyers), working undercover to expose and capture the fascist, Robey Leibbrandt (Ryno Hattingh), before he carries out his plan to assassinate General Smuts. Van Rensburg's themes of betrayal, the outcast, communication problems in relationships (in this case between Taillard and his wife) and Afrikaner nationalism are all present and brilliantly developed in the director's cut which runs for over three hours.

The controversy surrounding the production has suggested that the shorter theatrical version is perhaps not fully the film Van Rensburg made, and that to see his concept at its best one should watch the three-hour television version. But even the shorter version is still an impressive achievement: it depicts, as does Heroes, a time when the country was divided, as thousands of Afrikaner patriots, instead of joining the war effort, flocked to an ultra right-wing organisation violently opposed to the British.

Right-wing extremist sentiments are personified in the Leibbrandt character. He objects to his parents' friendship with a Jewish family. According to him, they are exploiting the Afrikaner nation. Later in the film, he and members of the Stormjaers blow up the shop of this Jewish family. During the recruiting of members, he remarks: "The Afrikaner grew up with his Bible in his one hand and his gun in the other. This 
is why we are still here." After this sequence, he starts a sabotage campaign.

The film is well structured and edited. Its linear structure involves two parallel narrative lines of Leibbrandt and Taillard respectively starting their missions, receiving instructions and making contact with crucial people. These storylines become one in both characters' involvement with a German woman. Taillard cannot tell his wife about his mission. His obsessive involvement in his work contributes to the separation between them. It is never resolved.

The Fourth Reich is one of the few South African films to make the great landscapes of this country (in particular the Cape Province, a recurring landscape within Van Rensburg's oeuvre) an integral part of the narrative structure.

Visually the film is hauntingly beautiful, photographed by Dewald Aukema. It fully deserved the 1990 AA Life Vita Award for best cinematography. The film's authentic images consist mostly of long shots of figures against the landscapes of a rural South Africa in contrast to medium and close-up shots of characters within darkly lit indoor settings.

Louis van Rensburg composed a remarkably authentic musical score for the film, developing specific musical themes for the key characters. Concertinas and violins were used throughout, as well as the Second Movement of Franz Schubert's Piano Trio in E-Flat Op 100, for the characterisation of the German woman, Frau Dorfman.

The failure of the film at the box office, however, was a shock for the industry. It cost some R16 million to make, raised mostly through the tax incentive scheme. The film opened with 20 prints, a saturated media and highly favourable reviews. Van Rensburg took best director at the Vita Awards. One explanation for its failure is that the main distributors, Ster-Kinekor, Nu Metro and UPI only cater for a small portion of the population. There are no cinema outlets to which blacks have easy access, the luxury complexes only being in the cities. Cinemas may be multi-racial, but outside the cities there are no substantial distribution chains to ensure that the majority of the South African population will see local movies.

The 1970s and 1980s: The Urban Afrikaner

Van Rensburg's best work is set in the past. His work about the psyche of the contemporary urban Afrikaner is placed within the conventions of light comedies like Die Square, suspense dramas like Die Vuurtoring and Die Bankrower, or adaptations of radio stories such as Geluksdal. Subsidy based on box-office income, censorship of political local films and the lack of audience demand for risky, experimental work during the seventies might have inhibited Van Rensburg in fully exploring contemporary issues. Although some of these films do not attain the same standard as his period dramas, they are still examples of Van Rensburg's thematic concerns, and Die Vuurtoring especially is a major achievement.

Country Lovers (1982)

Another notable film is a short fiction film based on the work of the South African writer, Nadine Gordimer. Country Lovers, depicts a contemporary love story across the racial barrier. The children of a white farmer and of the black farm labourers play together. Then comes the time when the white children go away to town for school and the black children begin to call their former playmates "Miss" and "Master". The film deals with the story of Paulus and Thebedi, former playmates who become lovers. Thebedi is courted and married by another of the farm labourers. She gives birth to a light-skinned child. The tragedy is inevitable.

The film was never screened on SABC TV and had a limited local festival and video release. Van Rensburg never had the freedom in his theatrical films of the 1970s as in the case of this short film, but these films do reflect some of his themes.

Freddie's In Love (1971)

Freddie's In Love, a financial failure, portrayed life in Hillbrow. In the depiction of a relationship between two lonely young people, Van Rensburg portrayed individual loneliness and communication problems between people within a contemporary urban context. These themes would later be more fully explored in the made-for-SABC drama, Die Vuurtoring.

Die Bankrower (1973) 
Die Bankrower (The Bank Robber) a suspense story, depicts the strategy of a burglar in a corrupt world. The burglar is Anton, the son of a wealthy bank owner. He has many risky ideas to make and invest money. His father, however, wants nothing to do with these plans. Anton, therefore, decides to demonstrate one of his plans. In order to do so, he needs money, which he steals from his father's bank. The film becomes quite intriguing when a real burglar steals the money from Anton. Die Bankrower is a well-made film, technically advanced for its time and an indication that an Afrikaans director can handle suspense successfully within this genre.

\section{Die Vuurtoring (1984)}

Van Rensburg's experimentation with film reached a peak in Die Vuurtoring (The Lighthouse). The hero, Wim Kleynhans, (played by Johan van Jaarsveld) lives an anti-social existence on the "edge" of modern, urban society. Obsessed with his work, he communicates more with his computer than with his wife, even addressing the computer as "Darling"! The patience he shows the computer is absent in his relationship with his wife. Their sterile marriage is symbolised by the clinical setting of their modern household, which Van Rensburg makes white throughout. The characters wear black clothes in sharp contrast to their surroundings and hide their emotional insecurity behind health-conscious practices.

The lighthouse becomes the symbol of a dissection of the inner worlds of these characters, their betrayal and personal conflicts. Wim becomes involved with a sinister organisation that contracts him to break a computer code to obtain information about "female fashions". In trying to find the right code, the right language, he feeds the computer an impressive alphabet of terms, but in his communication with his wife, he uses only the most basic of sentences such as "I am working tonight" and "Goodbye".

As with Taillard in The Fourth Reich, the hero cannot tell his wife about the nature of his work. He also cannot find the time to talk to her, like Horace in Taxi to Soweto. His wife, Helena, becomes involved in a relationship with another man, Leon Wessels.

At the end of the film, Wim does break the computer code and realises that the database consists of detailed information of missiles. He also finds secret video recordings of his wife's infidelity, as well as their conversations at home. During this sequence he realises the sterility of their marriage. As in the case of the main character in Die Perdesmous, he turns to violence.

This drama allows a free interpretation by means of an open structure. The contrast between the disintegration of human communication and the artificial, sophisticated world of technical communications (accentuated by shots of the interior of a telephone exchange and switchboard, a video camera, the use of an answering machine, and a television) is portrayed by means of alternating black and white with colour shots in a structurally fragmented way. The world of this ambitious television drama is an Orwellian one, full of paranoia and corruption within the ranks of a sinister organisation, not much different from the historical settings of Van Rensburg's period work.

Taxi to Soweto (1991)

In this Ster-Kinekor released film, Van Rensburg sets himself the tricky task of balancing sentiment and humour. Taxi to Soweto principally concerns a bored, middle-of-the-road, middle-aged, over-pampered, rich, urban Afrikaans woman, Jessica du Toit (played by Van Rensburg's regular, Elize Cawood), her workaholic husband, Morace (Marius Weyers) and a snappy street-sharp taxi-driver, Richard (Patrick Shai), whose lives become entwined despite the chasm known as the great South African racial divide.

Horace and Jessica's marriage has settled into stagnation in the "wastefully wonderful white-washed world of the old South Africa". But, a series of unexpected events signals a swift reversal. On her way to fetch Horace from the airport, Jessica's car breaks down. She is "rescued" by Richard who in turn is hijacked at gunpoint and Jessica is thrown headlong into "the black experience" of Soweto. Her restricted perspective of South African life is about to change forever.

Van Rensburg explores communication problems within many spheres of South African society: between people of different race groups and especially within the urban rat-race of wealthy whites. He does not flinch from showing the class differences between people living in poverty in sectors of Soweto and the rich whites of the northern urban areas of Johannesburg. 
Horace and Jessica's life is characterised by a lack of communication due to Horace's obsession with his work. As in the case of Die Vuurtoring, communication takes place within the restrictions of telephone answering machines and short telephone calls. Horace and his employer simply do not have the time for personal phone calls from their wives. Horace and Jessica's house looks like a fortress, with a sophisticated security system, a vicious dog and high security fences. The purpose is to keep the "enemy" out. In a very funny moment in the film, this security system literally backfires on Horace when he is attacked by his own dog and the security agency considers him to be a burglar.

When Horace arrives home after a business trip his world crumbles on finding a message from a black man on the answering machine, referring to Jessica as "Baby". He starts a long quest to find her. Suddenly his work loses its meaning. The quest resembles a similar process in Die Square, a comedy about a so-called pure Afrikaner, who loses his wife and sets out to look for her in the "strange" urban world of Hillbrow, in many ways alien to pure Afrikanerdom.

As in the case of Die Vuurtoring, the hero in Taxi to Soweto is confronted with his failed marriage by means of an audio-visual recording. Horace sees the break-up of his relationship with Jessica in the form of a television soapie. In a way this sequence becomes a critical comment on the portrayal of relationships in the Afrikaans film "soapies" of the local industry during the seventies.

The people who bring Jessica and Horace together again are, in fact, the "enemy" the blacks from Soweto. Jessica and Horace do get a new perspective on their lives and marriage, and on a changing South Africa. Unlike the pessimistic ending of Die Vuurtoring, their marriage is saved.

In Taxi to Soweto there are no outcasts, nor liberal whites who fight for the rights of blacks such as in $A$ Dry White Season (1988), nor are there the ultra-right-wing Afrikaner stereotypes of Roodt's A Place of Weeping (1984). A human face, although critical, is given to both the activists and the rich whites.

The film was shot in Soweto and Johannesburg. Several languages have been used: Afrikaans, English and some indigenous black languages. This reflects the rich cultural diversity Van Rensburg is portraying. In many ways this is the first filmic presentation of the dawn of a post-apartheid South Africa.

\section{Conclusion}

Manie van Rensburg's chronicles of Afrikanerdom are noted for their humane treatment of the characters, including outcasts and the political right wing. These films and television dramas are more than mere profiles of the politics of the time. Most of his work addresses communication problems between people in a universe that is characterised by distrust, paranoia and eventually betrayal. Even comedies such as Die Square and Taxi to Soweto address the issue of mistrust between humans. Van Rensburg's work as a whole gives a portrait of the strange, complex and divided creature who is the Afrikaner. This portrait is an important alternative to the oversimplified images of Afrikaners as mere racist villains usually depicted in anti-apartheid images of this troubled society.

Van Rensburg placed himself within the Afrikaans lager and, with films such as Die Square and Verspeelde Lente, managed to upset the establishment. Die Square caused a stir by depicting Afrikaners as hypocrites. Verspeelde Lente upset Afrikanerdom with its images of poor, lower class Afrikaners. Being Afrikaans was a source of tension, but also creativity in his work. He wasn't interested in portraying Afrikaner history, but in exploring Afrikaners in the larger history of the country. Later, examinations of racism and anti-Semitism became important themes in his work such as The Native Who Caused All the Trouble, Heroes and especially The Fourth Reich. The latter examined the destruction caused by power, racism and anti-Semitism.

If his work has a common theme, it is the conflict between the outsider and communal acceptance, an aspect he experienced in real life. His trip to Dakar during the repressive days of PW Botha got wide, somewhat hysterical publicity in Afrikaans newspapers, and meant an effective end to his career in the local mainstream film industry and unofficial blacklisting by the SABC.

He divided his career into his pre- and post-Dakar periods. Before Dakar he had work. After Dakar he found himself out of business. He was suddenly a filmmaker in search of a spiritual home; after being a sought-after, popular director, he struggled to make films. And the Left also held pitfalls. I remember an interview with him where he stated his dissatisfaction with FAWO. Someone there phoned him and asked 
why he hadn't yet submitted his script on Taxi to Soweto for approval. His answer was unprintable. He didn't need anyone's seal of approval, from the Right or the Left. He was too honest to take an approved political point of view, and too independent to leave artistic and political judgment to others. At the time of his death, he was only 48 years old. M-Net's award for Lifetime Achievement in film is named after Van Rensburg.

\section{Notes}

The Ossewabrandwag, or Brigade of Oxwagon Sentinels, a paramilitary, ultra-nationalist mass movement, was formed in 1939 after the Voortrekker centenary celebrations. It sought to arm the Afrikaner nation for the coming struggle to conquer the English-dominated urban centres.

2. Storm troopers, similar to the Nazi Sturmabteilung

\section{References}

Accone, D. Salvation of SA film in 'better Govt funding'. The Star Tonight!, 19 Jan. 1990a: 1-2.

Accone, D. Some see new film subsidy as disaster. The Star Tonight!, 1 March 1990b: 1.

Bauer, C. Breaking the local no-sound barrier. Weekly Mail, 2 April 1987: 21.

Blignaut, J. 1990. The distribution dilemma of local product. In: Blignaut, J. \& Metz, C. (eds.) Showdata Bulletin Vol. 2. Johannesburg: Showdata, 2-3.

Blignaut, J. \& Botha, M.P. (eds.) 1992. Movies Moguls Mavericks: South African Cinema 1979-1991. Auckland Park, Johannesburg: Showdata.

Botha, M.P. Probleme om oplewing in S.A. film. Die Volksblad, 4 Jan. 1990: 6.

Botha, M.P., Blignaut, J. \& Swanepoel, J. 1992. The problems of the mainstream film industry in South Africa. Paper read at a conference on "De Weerspiegeling van de Zuidafrikaanse socio-politieke realiteit in de onafhankelijke film" in Brussels, Belgium, from 4-8 May 1992.

Botha, M.P. \& Burger, F. A weathervane in uncertain winds. Weekly Mail, 14 - 20 Jul. 1989: 21, 24.

Botha, M.P. \& Van Aswegen, A. 1992. Images of South Africa: The rise of the alternative film. Pretoria: Human Sciences Research Council.

Currie, W. 1989. Film and video workers organise. South African Labour Bulletin, 14(5): 7-12

Davies, J. 1989. S.A. Film: A brief history. ADA, 6:32-33.

Fourie, P.J. 1981. 'n Struktureel-funksionele model vir die formulering van 'n Suid-Afrikaanse rolprentbeleid. Pretoria: UNISA. (Ongepubliseerde doktorale tesis)

Fourie, P.J. 1982. Interkulturele probleme in beeldkommunikasie. Communicare, 3(1): 60-73.

Gavshon, H. 1983. Levels of intervention in films made for African audiences in South Africa. Critical Arts 2(4): 13-21.

Metz, C. 1990. FAWO. In: Blignaut, J. \& Metz, C. (eds.) Showdata Bulletin, Vol. 7. Johannesburg: Showdata, 1,4 .

Nathan, J. 1991. Movies and monopolies: The distribution of cinema in South Africa. Staffrider 9(4): 61-84.

Powell, I. A snip off the old film subsidy scheme. Weekly Mail, 2 - 8 March 1990: 21-22.

Pretorius, W. 1992. Afrikaans cinema. In: Blignaut, J. \& Botha, M.P. (eds.) Movies Moguls Mavericks: South African cinema 1979-1991. JHB, Showdata, 375-394.

Schoombie, S. 'Die pasiënt is doodsiek'. Kalender, bylae tot Beeld, 12 Februarie 1990: 2. 
Silber, G. Tax, lies and videotape. The Executive, June 1990a: 68-74.

Silber, G. 1990b. Who killed the South African film industry? In: Blignaut, J. \& Metz, C. (eds.) Showdata Bulletin, Vol. 4. Johannesburg: Showdata, 2-4.

Tomaselli, K.G. 1989. The cinema of Apartheid: Race and class in South African film. Sandton: Radix.

Tomaselli, K.G. 1990. Cultural reconstruction in South African Cinema. In: Blignaut, J. \& Metz, C. (eds.) Showdata Bulletin, Vol. 5 Johannesburg: Showdata, 2-4.

Van Zyl, J. 1985. A reeling industry: Film in South Africa, Leadership S.A. 4(4): 102-106.

\section{Author Information}

Martin P. BOTHA is Associate Professor of Film and Media Studies at the University of Cape Town. He has published more than 200 articles, reports and papers on South African media, including six books on South African cinema. His most recent book is South African Cinema 1896-2010 (Bristol: Intellect, 2012). 